\title{
Canada's response to female genital mutilation: Are we failing our girls?
}

\section{Corinne Packer PhD, Vivien Runnels PhD, Ronald Labonté PhD}

Competing interests: None declared.

This article has been peer reviewed.

Correspondence to: Corinne Packer, cpacker@uottawa.ca

CMAJ 2015. DOI:10.1503 /cmaj.141215
I n 1997, the Parliament of Canada passed an amendment to the Criminal Code of Canada expressly prohibiting all forms of female genital mutilation in Canada. Under the code, it is prohibited to aid, abet or counsel such assault and to interfere with genitalia for nonmedical reasons. Moreover, the amendment expressly prohibits the transport of a child outside of Canada for the purpose of obtaining female genital mutilation. Anyone found to have carried out these offences faces up to 14 years in prison and/or a fine. ${ }^{1}$ Eighteen years on, there has not been a single prosecution for this offence in Canada. One could conclude from this that female genital mutilation is not performed in Canada, or that new Canadians, on their visits back to countries where this is practised, do not experience female genital mutilation. But we should not discount the possibility that the practice continues behind closed doors, as seems to be the case in a number of Western countries that have similarly banned the practice for years, yet have only recently seen charges being laid.

Female genital mutilation involves the cutting or removal of a girl's genitals and reconfiguration of the genital area. In the most extreme cases, a girl's entire labia and clitoris are cut off. At a minimum, this practice interferes with the female experience of sexual intercourse and childbirth. The physical, psychological, sexual and socially harmful effects of female genital mutilation have been well-documented, including the risk of death to infants and girls. ${ }^{2,3}$

The United Kingdom, whose Female Genital Mutilation Act came into effect nearly 30 years ago, ${ }^{4}$ recently charged Dr. Dhanuon Dharmasena under the act. ${ }^{5}$ Before this, 190 cases of female

\section{KEY POINTS}

- Female genital mutilation has been banned in Canada since 1997.

- Other Western countries that have also long banned the practice have recently seen prosecutions, but there have been no prosecutions in Canada.

- A number of countries are taking proactive measures to prevent the practice; Canada should consider adopting preventive measures as well. genital mutilation had been reported to the London Metropolitan Police Service in England since 2010, resulting in 12 arrests but no charges. ${ }^{6}$ There are numerous anecdotal reports of "cutting" being a common practice in the UK. ${ }^{6}$ It was alleged that Dharmasena restored a genital mutilation on a woman in a London hospital, at the encouragement of her husband, following delivery of the woman's baby. The woman's husband also faced one charge of aiding, abetting, counselling or procuring Dharmasena to commit an offence. Dharmasena was recently found not guilty. ${ }^{5}$

Australia began prosecuting cases of female genital mutilation in 2014. A mother and a nurse are standing trial for performing the act on the mother's daughters, aged six and seven. ${ }^{7}$ A local Sheik is also charged in the case for allegedly encouraging locals to lie to police about the prevalence of the procedure in the community. ${ }^{7}$ In a second Australian case, a father is facing charges for allegedly arranging for his young daughter to undergo female genital mutilation during a holiday overseas. As in the UK, there is anecdotal evidence in Australia that the practice is common, coming to light occasionally when medical complications arise.

In 2009, a Danish case resulted in a two-year sentence for a mother who allowed her daughters to be subjected to female genital mutilation during a stay in Sudan. France, which has a very similar criminal law to Canada concerning female genital mutilation, has successfully prosecuted more than 40 cases. ${ }^{8}$

Given the experience of other countries with immigration profiles similar to Canada, it would be naive to assume that Canadian girls are safe from the practice of genital mutilation. Moreover, Canada has a high rate of immigration, with the highest proportion of foreign-born populations among the G8 countries. The estimated prevalence of female genital mutilation in girls and women is $98 \%$ in Somalia, 91\% in Egypt, $89 \%$ in Eritrea and $88 \%$ in Sierra Leone, ${ }^{9}$ all countries from which Canada has received many female immigrants. Canada receives immigrants who have undergone the practice in their coun- 
tries of origin, and physicians are advised on how to treat medical problems stemming from the procedure. ${ }^{10}$

Other Western countries are actively taking measures to prevent this practice. In 2012, the Dutch government launched a declaration against female genital mutilation known as the "Health Passport," intended to help at-risk girls and their parents to resist familial pressure to carry out the practice when visiting countries of origin. ${ }^{11}$ A campaign is now underway in the UK for immigrants to sign a declaration promising not to subject their daughters to the practice before being allowed to enter the country. ${ }^{12}$

Prosecutions for female genital mutilation are sensitive because they may require a girl to implicate her own parents in a crime, and it is difficult to obtain reliable evidence of a crime carried out abroad. However, it is likely that we are not doing enough to protect girls and women who are at risk of undergoing this procedure that is outlawed in Canada. It is time that we take proper steps to prevent female genital mutilation, such as those initiated by other countries with similar immigration profiles.

\section{References}

1. Bill C-27: An Act to Amend the Criminal Code (child prostitution, child sex tourism, criminal harassment and female genital mutilation), 2nd Sess, 35th Parl, 1997.

2. Berg RC, Underland V. The obstetric consequences of female genital mutilation/cutting: a systematic review and meta-analysis. Obstet Gynecol Int 2013;2013:496564.
3. Vloeberghs E, van der Kwaak A, Knipscheer J, et al. Coping and chronic psychosocial consequences of female genital mutilation in The Netherlands. Ethn Health 2012;17:677-95.

4. Female Genital Mutilation Act 2003. London (UK): UK Parliament; 2003. Available: www.legislation.gov.uk/ukpga/2003/31 /contents/enacted (accessed 2015 Feb. 2).

5. CPS defends decision to bring FGM case against doctor acquitted in 30 minutes. London (UK): The Guardian; 2015. www.the guardian.com/society/2015/feb/05/cps-chief-alison-saunders-fgm -case-doctor-acquitted-30-minutees (accessed 2015 Feb. 9).

6. Female genital mutilation: woman arrested at Heathrow. London (UK): BBC News; 2013. Available: www.bbc.com/news /uk-england-london-27348776 (accessed 2015 Feb. 2).

7. Crawford S. Sydney sheik, mum and nurse to face mutilation judgment. Sydney (Australia): Daily Telegraph; 2014.

8. France reduces genital cutting with prevention, prosecutions lawyer. London (UK): Thomson Reuters Foundation; 2012. Available: www.trust.org/item/?map=france-reduces-genital-cutting -with-prevention-prosecutions-lawyer (accessed 2015 Feb. 2).

9. Female genital mutilation/cutting: a statistical overview and exploration of the dynamics of change. New York: UNICEF; 2013.

10. Senikas V, Davis V, Burnett M, et al. Clinical practice guideline: female genital cutting. J Obstet Gynaecol Can 2013 ; 35(11):e1-e18. Available: http://sogc.org/guidelines/clinical -practice-guideline-female-genital-cutting (accessed 2015 Feb. 5).

11. Exterkate M. Female genital mutilation in The Netherlands: prevalence, incidence and determinants. Utrecht (The Netherlands): Pharos Centre of Expertise on Health for Migrants and Refugees; 2013. Available: www.awepa.org/wp-content /uploads/2013/05/Female-Genital-Mutilation-in-the-Netherlands .pdf (accessed 2015 Feb. 2).

12. Davis A. Immigrants should sign FGM declaration before entering UK. London (UK): London Evening Standard; 2014 Available: www.standard.co.uk/news/health/immigrants -should-sign-fgm-declaration-before-entering-uk-9336296.html (accessed 2015 Feb. 2).

Affiliations: Department of Epidemiology and Community Medicine, Faculty of Medicine, University of Ottawa, Ottawa, Ont.

Contributors: All of the authors contributed substantially to the conception and design of the commentary, drafted the article, gave final approval of the version to be published and agreed to act as guarantor of the work. 